\title{
Daily Versus Weekly Supplementation with Iron, Vitamin A, Folic Acid and Vitamin C to Improve Iron and Vitamin A Status of Female Adolescents*
}

\author{
Imelda T. Angeles-Agdeppa**
}

\begin{abstract}
Abstrak
Prevalensi anemia di negara berkembang masih tetap tinggi meskipun program suplementasi tablet besi-asam folat telah dilaksanakan dalam skala besar. Dampak suplementasi dipengaruhi oleh berbagai faktor seperti rendahnya kepatuhan minum tablet, efek samping yang kurang disukai, persediaan tablet kurang, rendahnyajangkauan program, status vitamin $A$ yang rendah dan hambatan absorpsi zat besi karena suplementasi zat besi setiap hari.

Strategi yang mungkin dapat dilakukan untuk menurunkan prevalensi dan mengatasi masalah operasional adalah pemberian suplemen multi-vitamin mineral selama masa remaja dengan dosis lebih rendah dan frekuensi pemberian yang lebih jarang/tidak setiap hari.

Suatu penelitian kros-seksional telah dilakukan untukmendapatkan informasi dasar tentang status gizi dan kesehatan remaja lakilaki serta putri yang telah mendapat haid pada tiga buah sekolah menengah yang dipilih secara acak di Jakarta Timur. Usia rata-rata remaja laki-laki adalah 14,8 tahun dan remaja putri 15,6 tahun. Para remaja tersebut berasal dari keluarga golongan sosial ekonomi menengah. Prevalensi "thinness" lebih tinggi pada laki-laki (43\%) dari pada yang putri (10,2\%) dan kelebihan berat badan lebih banyak pada remaja putri $(32,9 \%)$. Prevalensi "stunting" pada remaja laki-laki dan putri (22\%). Prevalensi anemia lebih tinggi pada remaja putri $(21 \%)$ daripada laki-laki $(2,5 \%)$.

Setelah penelitian kros-seksional, dilakukan intervensi/suplementasi dengan tujuan menentukan pengaruh multi-vitamin-mineral dalam berbagai dosis pada hemoglobin, feritin plasma dan status vitamin A remaja putri. Tiga ratus enam puluh tiga subyek dipilih secara acak yaitu remaja putri yang telah mendapat haid, dengan kisaran usia 14-18 tahun dan tidak menderita demam, infeksi saluran nafas, atau penyakit gastro intestinal. Pengelompokan subjek menjadi 4 kelompok perlakuan (tiga kelompok mendapat suplemen dan satu mendapat plasebo) dilakukan secara "double-blind". Pil suplemen yang mengandung: $60 \mathrm{mg}$ zat besi el, 2500 SI vitamin A, $250 \mathrm{~g}$ asam folat, dan $60 \mathrm{mg}$ vitamin C diberikan kepada kelompok dosis harian (DD); $60 \mathrm{mg}$ zat besi el, 20000 SI vitamin A, $500 \mathrm{~g}$ asam folat dan $60 \mathrm{mg}$ vitamin C untuk kelompok setiap minggu dosis rendah (WLD); $120 \mathrm{mg}$ zat besi el, 20000 SI vitamin A, $500 \mathrm{~g}$ asam folat dan $60 \mathrm{mg}$ vitamin $C$ untuk kelompok setiap minggu-dosis tinggi (WHD), dan kelompok terakhir diberi pil plasebo (PL). Pil multi-vitamin dan mineral tidak dapat dibedakan dari pil plasebo secara kasat mata. Sebelum suplementasi didapati prevalensi anemia yang tinggi (21\%), feritin plasma rendah ( $37 \%)$, dan retinol plasma rendah (31\%).

Suplementasi selama 8 minggu menaikkan secara bermakna kadar hemoglobin (Hb), feritin plasma (FP), retinol plasma (RP), tinggi badan dan skor tes prestasi sekolah, semua kelompok yang mendapat suplemen. Kenaikan kadar FP kelompok dosis harian (DD) lebih besar (bermakna) daripada kelompok dosis setiap minggu.

Penambahan vitamin A dalam pil suplemen meningkatkan kadar RP dan rupanya berpengaruh pada penggunaan zat besi secara efisien untuk eritropoiesis. Peningkatan pada kelompok plasebo $(P L)$ tidak jelas sebabnya, tetapi ada kemungkinan pengaruh obat cacing.

Peningkatan prestasi sekolah dapat disebabkan oleh peningkatan penyediaan zat besi dalam otak dan distribusinya ke sel-sel otak yang penting untuk kelancaran fungsi neuron "dopaminergic". Suplementasi multi-vitamin dan mineral dapat memacu pertumbuhan linier tetapi tidak mengkompensasi kehilangan awal. Bertambahnya tinggi badan karena suplemen multi-vitamin-mineral dapat dikaitkan dengan perbaikan status zat besi yang meningkatkan oksidasi dan penyediaan energi untuk propliferasi sel. Prevalensi "stunting", "thinness" dan kelebihan berat tidak berkurang. Berat badan rupanya tidak dipengaruhi oleh suplementasi multi-vitamin dan mineral. Peningkatan masa suplementasi sampai 12 minggu tidak menghasilkan peningkatan Hb dan RP pada kelompok multi-vitamin dan mineral, tetapi memberikan waktu yang lebih lama untuk meningkatkan (bermakna) FP pada kelompok dosis mingguan. Pada kelompok dosis harian (DD) kadar FP bertambah tetapi tidak berbeda bermakna dari kadar pada minggu ke 8.

Tidak ada perbedaan efek dosis-frekuensi dari berbagai komposisi pil multi-vitamin dan mineral untuk seluruh masa suplementasi kecuali kenaikan FP yang menyolok kelompok dosis harian (DD) pada minggu ke-8. Selama masa I2 minggu, "individual lobe counts" darigranulosit (gejala defisiensi asam folat) setiap kelompok dalam kisaran normal sedangkan subjek penelitian tidakmenderita demam, infeksi saluran pernafasan dan infeksi saluran pencernaan. Dengan demikian penyebab anemia dalam penelitian ini disebabkan oleh kekurangan zat besi dan'atau kekurangan vitaminA.

Pada minggu ke 36 (24 minggu atau 6 bulan setelah akhir suplementasi) subyek yang sama diperiksa lagi untuk menilai sisa pengaruh suplementasi multi-vitamin-mineral pada kadar $H b, F P, R P$ dan pertumbuhan badan.
\end{abstract}

* Summary of the Dissertation leading to the Doctorate Degree in Nutrition at the University of Indonesia under the auspices of the Rector Professor M.K. Tadjuddin, for the public defence at the Senate Committee University of Indonesia on Wednesday, 16 October 1996

** SEAMEO-TROPMED University of Indonesia, Jakarta, Indonesia 
Semua kelompok yang mendapat suplemen, kadar RP dan tinggi badannya tetap lebih tinggi secara bermakna. Kadar Hb yang lebih tinggi (bermakna) hanya terdapat pada kelompok mingguan-dosis- rendah (WLD), sedangkan kadar FP yang lebih tinggi ditemukan pada kedua kelompokminggu (WLD, WHD). Kadar Hb dan FP cenderung menurun mulai akhir suplementasi sampai minggu ke 36 sesudahnya.

Oleh sebab itu suplementasi mingguan dengan pil dosis rendah (WLD) yang mengandung $60 \mathrm{mg}$ zat besi el, dan 20000 SI vitamin A, $500 \mathrm{~g}$ asam folat dan $60 \mathrm{mg}$ vitamin C selama 12 minggu, dapat dipertimbangkan sebagai strategi pencegahan untuk meningkatkan kesehatan, status gizi, dan skor tes prestasi belajar para remaja sebelum hamil. Suplementasi berkala perlu dilakukan setiap 6 bulan. Namun demikian perencana program perlu memperhatikan bahwa meskipun program suplementasi besi adalah jalur utama untuk menanggulangi anemia, di dalamnya harus ada pendidikan gizi antara lain tentang petunjuk aluran minum pil suplemen. Suatu strategi campuran yang seimbang yang terdiri dari strategi jangka menengah yang berhubungan dengan fortifikasi pangan dan sirategi jangka panjang yang bertujuan mengubah kebiasaan makan melalui pendidikan gizi harus menjadi bagian program suplementasi zat besi untuk memastikan kesinambungan program.

Penelitian lebih lanjut dengan jumlah subyek yang lebih besar perlu dilakukan untuk menunjang/menegaskan hasil penelitian ini dan mengetahui peranan kekurangan zat gizi lain yang berkaitan dengan anemia seperti protein, $C u$, vitamin B2, vitamin B6, dan vitamin B12. Kadar RP yang tidak berubah pada minggu ke 12 perlu diteliti lebih lanjut. Dosis vitamin yang lebih rendah (10.000 SI) mungkin cukup untuk meningkatkan kadar retinol. Selain itu karena keterbatasan waktu penelitian ini perlu dilakukan penelitian longitudinal suplementasi multi-vitamin-mineral mingguan dosis rendah (WLD). Penelitian operasional tentang sistem penyampaian (delivery system) suplemen multi-vitamin-mineral di sekolah-sekolah juga penting dipertimbangkan.

\section{Background Information and Problem Statement}

In many developing countries like Indonesia, iron deficiency (ID) remains prevalent $(50-52 \%$ in pregnant women). ${ }^{1,2}$ To decrease the prevalence many developing countries initiated iron supplementation programs for pregnant women. WHO recommended that all pregnant women should have a daily intake of $120 \mathrm{mg}$ iron $(\mathrm{Fe})$ and $250 \mathrm{mg}$ folate starting at the second trimester of pregnancy through the public health system. However, the impact is limited, a phenomenon which is true in all developing countries. ${ }^{3}$ Based on WHO recommendation, a total of 120 pills would be taken for the whole period of pregnancy, however, the Indonesian Demographic and Health Survey ${ }^{4}$ revealed that, among women whose last born-child was born in the five years before the survey, only $14 \%$ took at least 90 iron pills during pregnancy, and $26 \%$ took none. Low coverage, inadequate supply of iron pills at health centers, poor compliance, and undesirable side-effects were the reasons considered contributing to the limited effectiveness of the program. ${ }^{5,6}$ Negative side-effects are due to the high dose-effect of medicinal $\mathrm{Fe}$ given everyday in the gastrointestinal tract. ${ }^{7}$

To address this problem, recent studies have been carried-out to improve iron status by administering $F e$ supplements on reduced frequencies. Findings revealed that $\mathrm{Fe}$ given either less frequently per week or once weekly have similar effects in improving the iron status as daily supplementation. ${ }^{8-11}$ During daily supplementation, iron concentrations become very elevated in the liver and particularly in the lumen and mucosa of the gut causing iron blockage. ${ }^{12,13}$ Iron blockage occurs because of iron saturation in the cells. Theoretically, by spacing, iron dosage blockage is avoided because the gut mucosal turnover or renewal is between 5 to 6 days. Iron given weekly should then be more efficient than iron given daily or once every 3 days because iron is administered to new cells that have not been exposed to iron. ${ }^{14}$ Weekly iron supplementation might be a safe and effective way to prevent $\mathrm{ID}$ and iron deficiency anemia. ${ }^{15}$

ID is the main cause of anemia. The most common causes of ID in developing countries are poor dietary iron intake, blood loss due to parasitic infestation and/or menstruation, low bioavailability due to high phytate content of foods and the absence of iron enhancers like vitamin $C$ in the meal. ${ }^{16,17}$ Vitamin $C$ enhances the absorption of non-heme $F e .^{18}$ It also promotes the utilization of heme-iron by enhancing the incorporation of iron in its storage form, ferritin. ${ }^{19}$

Earlier findings revealed that vitamin A deficiency (VAD) can also cause anemia which is refractory to $F e$ supplements but responsive to vitamin $\mathrm{A}^{20}$ During VAD iron is trapped in the liver making it unavailable to the tissues for physiological functions. ${ }^{21}$ Correcting this condition by the administration of vitamin A will stimulate the synthesis of transferrin. Transferrin is a transport iron, thereby, this would increase the availability of iron for hematopoiesis.

The non-incorporation of vitamin A in the Fe supplements despite of the poor vitamin A status of pregnant women ${ }^{22,23}$ may further aggravate the anemia problem.

Anemia other than $\mathrm{ID}$ is megaloblastic anemia caused by folic acid deficiency. Most $\mathrm{Fe}$ pills are combined with folic acid (FA). FA is responsible for the maturation of red blood cells (RBC) and white blood cells (WBC). ${ }^{24}$ 
The existing iron supplementation program to control anemia targeted to pregnant women is too late because anemia already exists. The probable strategy therefore, is to prevent the occurrence of anemia prior to pregnancy. Data showed that $25 \%$ of girls around the world will have had their first child by age 19 years. ${ }^{25}$ In Indonesia, it was reported that $11.2 \%$ teenagers have begun child bearing. Adolescence is therefore, the ideal time to improve pre-pregnancy iron status.

The Indonesian long term plan for the control of anemia in women confirmed that one of the priority targets were the adolescent girls. ${ }^{26}$ However, possible strategies remain uncertain up to the present. Their is a limited baseline data on the prevalence of anemia and supplementation trial has not been implemented to improve iron status. No study has been conducted to test how a particular combination of nutrients such as $F e$ with folic acid plus vitamins A and C may result in an increase in iron nutriture of female adolescents.

\section{Objective of the Study}

This applied, public-health-oriented research assessed the effectivess of different regimens of pharmaceutical multi- nutrient supplements in improving the iron and vitamin A status of female-school-going adolescents.

\section{Benefits of the Study}

This study can provide substantial information on whether :

1. Multi-nutrient supplementation is effective in improving the iron status of female adolescents which might result to the decrease in the prevalence iron deficiency prior to pregnancy. In this way, women would enter pregnancy with some iron reserves and that children would be born with better iron status. Furthermore, the chances of mitigating the anemia problems may be far better.

2. Multi-nutrient supplements given to school-going female adolescents would improve mental and cognitive performance.

3. Once a week low dose multi-nutrient supplementation would reduce the occurrence of side-effects, which would eventually lead to improved compliance.

4. Multi-nutrient supplements given for 8 weeks is as effective as 12 weeks in improving the iron, vitamin A status.

5. The effects of the multi-nutrient supplements on $\mathrm{Hb}, \mathrm{PF}$, and PR would still be retained 36 weeks after the termination of supplementation. This would serve as the basis for the determination of the interval of supplementation.

6. Results of the present study could be used as the basis for further investigations for a rational problem implementation.

\section{Causal Model of the Study}

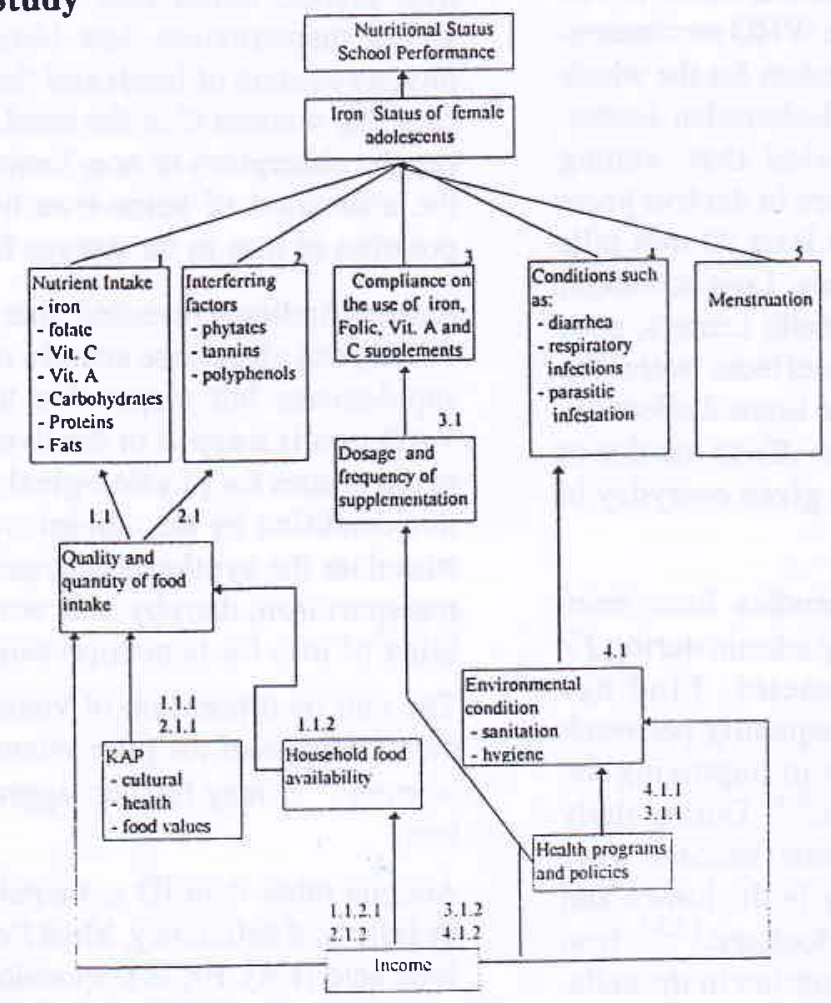




\section{Hypotheses}

1. Multi-nutrient supplemented groups have better $\mathrm{Hb}, \mathrm{PF}, \mathrm{PR}$, physical growth, and school performance test scores than the placebo group.

2. A weekly low dose (WLD) of $60 \mathrm{mg}$ el Fe with 500 $\mu \mathrm{g}$ folic acid plus $20000 \mathrm{IU}$ Vitamin A and $60 \mathrm{mg}$ Vitamin $\mathrm{C}$ is equally as effective as the supplements given weekly in a higher dose (WHD) of 120 $\mathrm{mg}$ el iron in improving hemoglobin, plasma ferritin, plasma retinol, physical growth, and school performance test scores.

3. A WLD (60 mg el iron) multi-nutrient supplement given to school- going females has similar effect on hemoglobin, plasma ferritin, plasma retinol, physical growth, and school performance test scores as a supplement of the same dose given daily.

4. Multi-nutrient supplements given for 12 weeks have similar effects on hemoglobin, plasma ferritin, plasma retinol, physical growth as the supplements given for 8 weeks.

5. After 36 weeks from the start of the intervention study, at least $50 \%$ of the multi-nutrient supplemented groups remain iron-replete ( $\mathrm{PF}>20 \mu \mathrm{g} / \mathrm{L}$ ) while the placebo group remain on a decreasing $\mathrm{PF}$ levels.

\section{Limitations of the Study}

This study does not intend to analyze the effect of each individual micronutrient composing the tablet. The effort and budget required are three to four times higher and it seems doubtful whether analyzing each single nutrient component of the pill is more efficient and provide better information as when analyzed as one supplement type since there is a nutrient- nutrient interaction.

\section{METHODOLOGY}

\section{Study Design}

This study was conducted in three phases: The first was a cross- sectional study. This was to obtain general information on the health and nutritional status of male and female adolescents. Males were included to confirm earlier review that men are less affected by anemia than women. ${ }^{27}$

Following the cross-sectional study was the second phase which was an intervention study. This was a public health-oriented, randomized, double blind, placebo-controlled community trial to improve the iron and vitamin A status of female-school going adolescents.

The third phase was a follow-up study. After 36 weeks from the start of the multi-nutrient supplementation, the female adolescents were followed-up and reassessed to determine the retention of effects of the multi-nutrient supplements as basis for the interval of supplementation.

\section{Study Sites, Subjects, and Multi-nutrient pills}

The cross-sectional study took place in three government high schools ( 2 junior and 1 senior high schools) in East Jakarta as recommended by the District Office of the Department of Education. A randomly selected 805 menstruating females and 118 males aged 13 to 18 years had willingly participated.

Out from the three high schools in the cross-sectional study, the senior high school was drawn randomly for the intervention study on multi-nutrient supplements. The sample size of each group ( 60 females) was calculated using the formula for community trial with a $95 \%$ C.I. and a $90 \%$ chance to detect a change in mean $\mathrm{Hb}$ of $5.4 \mathrm{~g} / \mathrm{L}$ and $0.12 \mu \mathrm{mol} / \mathrm{L}$ of retinol, which are considered to be biologically significant between groups. Allowing for a high attrition rate, the sample size was increased by $33 \%$. Using a simple random sampling, a total of 363 anemic and non-anemic females from the school registrar's list were allocated into 4 treatment groups at random each having 90 females per group. The prevalence of anemia in the survey was $21.1 \%$ which justified the decision of a blanket approach of supplementation as a preventive public health strategy. The females in the intervention study came from different grade levels and classes, aged ranging from 14-18 years old with $\mathrm{Hb}$ level of $>80 \mathrm{~g} / \mathrm{L}$.

None of the subjects in both cross-sectional and intervention studies were suffering from fever, respiratory infections, or gastro-intestinal diseases. All females had regular menstruation. All subjects belonged to the middle socio-economic group and were inhabitants of East Jakarta. Both the parent and the females gave their written consent to participate in the study.

Information on the content of the multi-nutrient supplement pills is provided in Table 1. 
Table 1. Composition of multi-nutrient supplements and dosage

\begin{tabular}{lcccc}
\hline Frequency & Iron $(\mathrm{mg})$ & ${\text { Vitamin A }(\mathrm{IU})^{3}}^{3}$ & Vitamin C $(\mathrm{mg})$ & Folic acid $(\mu \mathrm{g})$ \\
\hline Daily $^{1}$ & 60 & 2500 & 60 & 250 \\
Once weekly $^{2}$ & 60 & 20000 & 60 & 500 \\
Once weekly $^{2}$ & 120 & 20000 & 60 & 500 \\
Placebo & 0 & 0 & 0 & 0 \\
\hline
\end{tabular}

\footnotetext{
I supplements administered from Monday through Friday

2 supplements administered on Friday with a placebo from Monday-Thursday

3 retinol acetate.
}

Quality testing was conducted at Kimia Farma's Quality Control Department, Bandung. The amount of each nutrient in the pill were based on the following considerations: FAO/WHO's recommendation on $\mathrm{Fe}$ supplementation to adolescents in areas where there is moderate IDA $(>70 \mathrm{~g} / \mathrm{L} \mathrm{HB}<120 \mathrm{~g} / \mathrm{L}=10-39 \%$ of the population) is $60 \mathrm{mg} / 2$ times daily. ${ }^{17}$ The formulation of the amount of nutrients in the pills was guided by the RDA. ${ }^{28}$

\section{Conduct of the study}

All females were dewormed 3 days before the start of the intervention study, administering one single dose of $500 \mathrm{mg}$ mebendazole. This was to eliminate the effect of parasitism as a confounding factor.

The supplement pills were personally administered 5 days a week either by the principal researcher or by trained nutrition assistants for the first 8 weeks. A double blind approach was managed by packing the supplement pills in sealed plastics. One group received the true supplement pills on every school day of the week (Monday-Friday), two other groups received the true supplement pill only once a week and placebos on the other school days. The last group received placebos on every school day. The multi-nutrient supplements and the placebo pills were similar in appearance, size and color and were not distinguishable on sight. Pill codes were only revealed to the principal researcher after analysis of all data.

From week 9-12, thirty pill supplements were provided on a take- home basis after the females had received careful instructions on pill intake. Females were advised to take the pills 7 days a week. At 12 weeks, the females were asked whether they had taken all the pills. The pill containers were retrieved from all subjects and the remaining tablets were counted. Side-effects like nausea, vomiting, sleepiness, increased appetite, and diarrhea after pill intake were investigated at week 10 and 11.

\section{Measurements and methods of assessment}

\section{Interview}

During the cross-sectional study, a pre-tested questionnaire on general health and nutritional-related characteristics of subjects was administered.

\section{Fecal examination}

Before the start of the intervention study, fecal samples from $28 \%$ (104 out of 363) of the females were collected and analyzed using a modified Kato-Katz method $^{29}$ at the Parasitology Department of the University of Indonesia. A subsample was used because of financial constraint and the difficulty of collecting fecal samples.

\section{Hematology}

During the cross-sectional study, $\mathrm{Hb}$ concentrations of all subjects were estimated according to the cyanomethemoglobin method ${ }^{30}$ using a portable miniphotometer (Compur-Minilab 3, Bayer, Munich, Germany). Capillary blood was obtained from the left ring finger using an automatic skin puncturing device (Autoclix, Boeringer Mannheim, Mannheim, Germany).

During the intervention study, three cc of fresh venous blood was placed in vacutainers with $\mathrm{K}_{2}$ EDTA for analysis of $\mathrm{Hb}$ level and leucocyte differential count using a MAXM Coulter (Coulter Electronics Limited, Luton, Beds, England) at the Department of Pathology, Cipto Mangunkusumo General Hospital. Duplicate measurements for $12 \%$ of the samples for each period of measurement revealed a within-assay variability of $\pm 0.09 \mathrm{~g} / \mathrm{L}$. 
Another 5-6 cc of blood were placed in vacutainers with heparin to be centrifuged at the SEAMEO-TropMed laboratory. ${ }^{30}$ Two aliquots were prepared for plasma ferritin (PF) and plasma retinol (PR). These were stored at $-20^{\circ} \mathrm{C}$ without defrosting until the end of the study ( 36 weeks). ${ }^{30}$

PF was determined in all samples by microparticle enzyme immunoassay (MEIA) using a commercial kit (IMX System; Abbott, Abbott Park, IL). Duplicate analyses were performed for $12 \%$ of the samples and the within-assay variability was $\pm 0.25 \mu \mathrm{g} / \mathrm{L}$.

Anemia was defined as $\mathrm{Hb}<120 \mathrm{~g} / \mathrm{L}$ for females and $<130 \mathrm{~g} / \mathrm{L}$ for males. ${ }^{30} \mathrm{PF}<20 \mu \mathrm{g} / \mathrm{L}$ is the cut-off of low iron stores. ${ }^{31}$

WBC was analyzed using coulter counter. Normal values for WBC is $4.3-10.0 \times 10^{9} \pi$ of blood. ${ }^{32,33}$ Hypersegmentation of granulocytes was determined in blood smears by lobe counting. These analyses were done at the Department of Pathology, Cipto Mangunkusumo General Hospital. Normal lobe average is $3.17 .^{32}$

\section{Retinol levels}

An aliquot for retinol asssay was transported in ice buckets to the Nutrition Research and Development Center, Bogor, Retinol was analyzed using a high performance liquid chromatography (HPLC) ${ }^{34}$ Plasma retinol $(\mathrm{PR})<0.70 \mu \mathrm{mol} / \mathrm{L}$ reflects marginal vitamin A deficiency. ${ }^{34}$

\section{Anthropometry}

Weight and height were measured during the three phases of the study. Weight was recorded to the nearest $0.1 \mathrm{~kg}$ (model 770 alpha; SECA, Hamburg, Germany). Subjects were weighed between 09:00 and 11:30 hours with their school uniforms. Height was measured to the nearest $0.1 \mathrm{~cm}$ (CMS Weighing Equipment Ltd., London). Height-for-age $<3$ rd percentile is considered as stunting (WHO 1983, WHO 1995). Body mass index (BMI) was calculated as weight $/ \mathrm{height}^{2}\left(\mathrm{~kg} / \mathrm{m}^{2}\right)$. BMIfor-age $<5$ th percentile and $\mathrm{BMI} \geq 85$ th were regarded as cases of thinness and potential cases of overweight respectively. ${ }^{35,36}$

\section{Dietary assessment}

Dietary intake was assessed using a 3-d repeated 24-h food recall at the end of 8 weeks of the intervention study and at the follow-up study. Nutrient conversion was analyzed using the Indonesian Nutrient Analysis Program (INDONAP) ${ }^{37}$ Mean nutrient intake was calculated for the three days. Group intake was expressed in median and compared with RNI standards. ${ }^{38}$

\section{Morbidity}

The occurrence of illness were noted by the Nutritionists/Class Chairmen validated by the principal researcher everyday for the duration of 8 weeks. At 10th and 11 th weeks, females were asked if they have been ill for the past week.

\section{School performance and I.Q. Tests}

School performance test was assessed before and after 8 weeks of the intervention study using test questions developed by the Office of Education and Cultural Research and Development, Department of Education, Jakarta. These were administered by the staff of the Department of Education on two alternate days given specified time limits. Subjects included were language, physics, biology, and mathematics. Biology and physics were elective subjects.

The I.Q. test was administered before the start of the multi- nutrient supplementation study by the staff of the Department of Education using the Culture Fair Intelligence Test. ${ }^{39}$

\section{Statistical Analyses}

Data were processed and analyzed in SPSS (version 6.0; SPSS Inc, Chicago) and Epi-info 6 (USD Inc., West Park, GA) software packages. Nutrients composition of the dietary intake was determined using the Indonesian Nutrient Analysis Program (INDONAP). ${ }^{37}$

Prior to analysis, each varibale was tested for normality using the Kolmogorov Smirnov test. Descriptive characteristics were expressed as means $\left(\bar{X}_{ \pm} S D\right)$ for normally distributed data. Median was used for dietary intake data because it was not normally distributed. Plasma ferritin values used in the analysis were log transformed. ${ }^{38 a, 39 a}$

The statistical analyses used were: One-way analysis of variance (ANOVA), Bonferroni test procedure, paired t-test, independent t- test, multiple analysis of variance (MANOVA) for repeated measures, chisquare $\left(\mathrm{X}^{2}\right)$ test, $\mathrm{X}^{2}$ for trend, bivariate correlations, binomial proportions, Wilcoxon test and KruskalWallis. ${ }^{38 a, 39 a}$ 


\section{Ethical Considerations}

Anemic adolescents who were not selected for the intervention study were referred to the nearest health post. Ethical principles applied in this study was guided by the recommendations of the Council for International Organizations of Medical Sciences ${ }^{40}$ and received approval from both the Ethical Committee of the SEAMEO-TROPMED and the Ethical Committee for Post-graduate Program, University of Indonesia.

\section{RESULTS AND DISCUSSION}

This study had filled-up the gap of knowledge by providing information on the health and nutritional status of adolescents and provided possible strategy to improve health status of females prior to motherhood.

\section{CROSS-SECTIONAL STUDY}

Table 1. Selected characteristics of male and female adolescents

\begin{tabular}{|c|c|c|}
\hline Varibles & $\begin{array}{c}\text { Females } \\
(n=805)\end{array}$ & $\begin{array}{l}\text { Males } \\
(n=118)\end{array}$ \\
\hline Age (years) ${ }^{1}$ & $15.6 \pm 1.4$ & $14.8 \pm 0.7$ \\
\hline Weight $(\mathrm{kg})^{1}$ & $46.6 \pm 7.4$ & $46.0 \pm 9.4$ \\
\hline Height $(\mathrm{cm})^{1}$ & $153.4 \pm 5.2$ & $158.3 \pm 7.3$ \\
\hline $\mathrm{BMI}\left(\mathrm{kg} / \mathrm{m}^{2}\right)^{1}$ & $19.8 \pm 2.8$ & $18.2 \pm 2.7$ \\
\hline$\% \leq 5$ th percentile & 10.2 & 43.2 \\
\hline$\% \geq 85$ th percentile & 32.9 & 9.3 \\
\hline \multicolumn{3}{|l|}{ Stunded $(\%)$} \\
\hline$<3$ rd percentile ${ }^{\mathrm{NS}}$ & 22.0 & 22.1 \\
\hline Hemoglobin $(g / L)^{1}$ & $128.5 \pm 14.0$ & $145.0 \pm 11.3$ \\
\hline Anemia prevalence $(\%)$ & 21.1 & 2.5 \\
\hline
\end{tabular}

${ }^{1} \overline{\mathrm{X}}_{ \pm} \mathrm{SD}$

NS no significant difference between sexes.

Table 1 is the general characteristics of subjects. The prevalence of thinness (BMI $<<5$ th percentile) was higher in males than in female. The risk of being overweight was higher in females than in males $\left(\mathrm{X}^{2}=\mathrm{P}<0.01\right)$. No significant difference in rates of stunting between sexes. But anemia prevalence was higher in females than in males $\left(\mathrm{X}^{2}=\mathrm{P}<.001\right)$.

Thinness in males (Table 1) reflects that linear growth is faster than having weight gain while on the contrary, females gain weight faster than achieving a proportional height. Short stature and thinness in males may have negative effects on muscular strength and working capacity. ${ }^{41}$ Thinness in females can have negative ef- fects on pregnancy outcome ${ }^{42}$ and high incidence of morbidity ${ }^{43}$ while overweight ( $32.9 \%$ ) may pose a risk factor to adult chronic diseases like hypertension, coronary heart disease, diabetes mellitus and gallstones. ${ }^{44}$

Average weight of males and females were $8.4 \mathrm{~kg}$ and $8.8 \mathrm{~kg}(16 \%)$ lower while mean height was lower by $8.7 \mathrm{~cm}$ and $9.0 \mathrm{~cm}(5 \%)$ as compared to the US reference for this age (Table 1). ${ }^{45}$ The difference between the data in the US and the present results can be regarded as the differences in the timing of pubescent growth spurts across populations ${ }^{46}$ and that, genetically, Asians have shorter stature, lighter weight, and decreased body fat and lean body mass compared with US women. ${ }^{47}$ It was argued, however, that genetic effect if ever it exists, is less important than that of the environmental effect. ${ }^{48,49}$

High rate of stunting in both males and females sexes (Table 1 ) is a manifestation of previous chronic poor health and nutrition condition which has been regarded as an interplay between nutrient intakes and infection in early life. ${ }^{50}$

The onset of menarche is dependent on the attainment of minimum weight-for-height and a store of a certain level of fat which is an important source of estrogen. ${ }^{51}$ Average age at menarche of females in this study was 11.9 years. Martorell's review considers that menarcheal age between 13.5 and 14.9 years are considered to have had moderate delays. ${ }^{50}$ Considering this phenomenon, $23 \%$ of the females in this study had menarcheal age between 13 and 14.9 years who might have had delayed maturation. Late menarche and delayed growth especially in early prenancy may interfere with continued growth of the young mother and adversely affect birth outcome while early menarche signals better health and environmental exposures. ${ }^{36,52}$

The prevalence of anemia in females $(21 \%)$ was higher than in males $(2.5 \%)(\mathrm{P}=0.000)$. Since the subjects of this study come from middle income group, prevalence might be higher in the less previleged group of the society. Females are often expected to be more anemic than males because of the high iron needs $(15 \mathrm{mg} / \mathrm{d})$ to compensate for added losses during menstruation which ranged from $0.6-0.7 \mathrm{mg} / \mathrm{d}^{53}$ and continues to be high for the whole menstrual years while in males, increased iron needs is only observed during the pubescent growth spurt and sexual maturation then, begins to decrease thereafter. ${ }^{27}$ The iron requirement of adolescent females is difficult to meet with the present low iron intake ${ }^{53}$ suggesting the ned for a supplementation program. 


\section{INTERVENTION STUDY}

\section{Effects of multi-nutrient supplements on $\mathrm{Hb}, \mathrm{PF}, \mathrm{PR}$ Levels, Frequency, and Duration of Supplementa- tion}

Full results were available for 273 (75\% of the 363$)$ samples from baseline to 12 weeks. The characteristics of drop-outs in terms of age, weight, height, length of menstruation, body mass index (BMI), and initial hemoglobin $(\mathrm{Hb})$ level were not significantly different as compared to the values of these same variables in the remaining subjects for the intervention study. Common reasons for drop outs were: refusal to undergo blood extraction, absence from the class on the day of blood collection, and decided not to continue taking the pill.

\section{Baseline data}

At baseline, the age range of females was 14-18 years. There was no significant difference between groups in basal age, weight, height, BMI and period of menarche ( $\mathrm{P}>0.05$ ).

Table 2. Prevalence and confidence intervals of anemia, low plasma ferritin, and low plasma retinol levels in females before supplementation ${ }^{1}$

\begin{tabular}{llll}
\hline Study groups (n) & \multicolumn{1}{c}{ Anemia $^{\text {NS }}$} & Low PF & Low PR \\
\hline Daily (64) & $17.2(8.9-28.7)$ & $26.6(8.9-28.7)$ & $21.9(12.5-34.0)$ \\
Weekly,low (70) & $24.3(14.8-36.0)$ & $40.0(28.5-52.4)$ & $32.9(22.0-45.1)$ \\
Weekly, high (64) & $21.9(12.5 \pm 34.0)$ & $43.8(31.4-56.7)$ & $35.9(24.3-49.0)$ \\
Placebo (75) & $24.0(11.7-30.8)$ & $37.3(26.4-49.3)$ & $32.0(21.7-43.8)$ \\
Total (273) & 20.9 & 37.0 & 30.8 \\
\hline
\end{tabular}

${ }^{1} \%$; () $95 \%$ C.I.

anemia $=\mathrm{Hb}<120 \mathrm{~g} / \mathrm{L}$; low plasma ferritin levels $=\mathrm{PF}<20 \mu \mathrm{g} / \mathrm{L}$, Low plasma retinol $=\mathrm{PR}<0.70 \mu \mathrm{mol} / \mathrm{L}$.

$\mathrm{X}^{2}$-test : ${ }^{\mathrm{NS}}$ no significant difference between groups, $\mathrm{B}>0.05$

Also at baseline, there was a high prevalence of anemia, low plasma ferritin (LPF) and low plasma retinol (LPR) levels and that there was no significant difference between groups in initial rates of these variables $(P>0.05)$ (Table 2). Since it has been identified that $\mathrm{Fe}$ metabolism is disturbed in the course of VAD it is possible that anemia in the present study was aggravated by the high rate of suboptimal levels of plasma retinol (PR). The non-incorporation of vitamin $\mathrm{A}$ in the present $\mathrm{Fe}$ supplementation program in pregnant women despite of high prevalence of VAD in this population subset ${ }^{22,23}$ might be a factor of the still high prevalence of IDA.

\section{Effects of multi-nutrient-supplements at 8 weeks}

At the end of 8 weeks supplementation, there was an evident significant increase of basal $\mathrm{Hb}$ in the multisupplemented groups $(\mathrm{P}<0.001)$ (Table 3$)$. This may be attributed not only to $\mathrm{Fe}$ but also to vitamin $\mathrm{A}$ in the pills. Vitamin A may have enhanced the mobilization of $F e .{ }^{54}$ In a way, folate may have contributed to the maturation of $\mathrm{RBC}^{24}$ and vitamin $\mathrm{C}$ may had enhanced $\mathrm{Fe}$ absorption.

The similar increase in $\mathrm{Hb}$ in the different multi-suplemented groups at 8 weeks depicts similar efficacy of the supplements regardless of the frequency and dose of supplementation, that is either given as daily (DD), weekly low dose (WLD), or weekly high dose (WHD). Similarly, many scientists ${ }^{8,9,11,55}$ found that less frequent $\mathrm{Fe}$ administration, and high or low dose of elemental iron $(e l \mathrm{Fe})$ have similar effects in improving hemoglobin level.

The prevalence of anemia ( $D D=9.4 \%$; $W L D=12.9 \%$; WHD $=9.4 \%$ ) had decreased in all multi-nutrient supplemented groups. The PL had increased rate of $26.7 \%$. No significant difference was observed in anemia rates between multi-nutrient supplemented group $\left(\mathrm{X}^{2}=\mathrm{P}>0.05\right)$.

Considering the frequency-dose-effect on $\mathrm{PF}$, the $\mathrm{DD}$ had a significantly higher PF than the weekly groups $(\mathrm{P}<0.001)$ (Table 3). Similar findings were observed by Liu X-N in children. ${ }^{11}$ On the contrary, Ridwan et $\mathrm{al}^{55}$ found no significant difference between the daily and weekly doses in pregnant women. The high deposition of iron in the DD might have been due to the increased absorption because of low iron status at baseline. The presence of vitamin $\mathrm{C}$ in the pill may had enhanced the storage of $\mathrm{Fe}{ }^{18,19}$ In Indian non-lactating, non-pregnant tea pluckers, it was shown that higher doses of $\mathrm{Fe}$ (>100 $\mathrm{mg} e l \mathrm{Fe}$ ) are needed to build iron reserves. ${ }^{56}$

The prevalence of $\mathrm{LPF}(\mathrm{DD}=3.1 \%$; $\mathrm{WLD}=24.3 \%$; $\mathrm{WHD}=26.6 \%$ ) was significantly lower in the DD than in the weekly doses $(\mathrm{P}<0.0001)$. The PL had 45.3\%.

The effectiveness of vitamin A in increasing PR was observed in all multisuplemented groups $(\mathrm{P}<0.001)$ (Table 3). Similar results were revealed in different population subsets. ${ }^{54,57-59}$

The different regimens of multi-nutrient supplements had not resulted in any greater benefit over the weekly doses in improving PR levels $(\mathrm{P}>0.05)$. The prevalence of LPR levels was found only in the PL (7\%). 
Retinol levels were related with $\mathrm{Hb}$ and $\mathrm{PF}$ levels at baseline $(\mathrm{r}=0.22, \mathrm{P}=0.000 ; \mathrm{r}=0.20, \mathrm{P}=0.001)$, at 8 weeks $(\mathrm{r}=0.29, \mathrm{P}=0.000 ; \mathrm{r}=0.19, \mathrm{P}=0.002)$, and at 12 weeks $(r=0.31, P=0.000 ; r=0.30, P=0.000)$. Although the association of retinol to $\mathrm{Hb}$ is weak, this might have played a role in mobilizing iron in the synthesis of transferrin that makes iron available for hematopoiesis. Several scientists had revealed similar findings. $22,59-62$ The positive response of PF to the multi-nutrient supplements might be due to the immediate correction of VAD leading to increased utilization of iron. ${ }^{21}$

\section{Effects of multi-nutrient supplements at 12 weeks}

The results at 12 weeks did not show any increase in $\mathrm{Hb}(\mathrm{P}>0.05)$ but resulted to further increase in $\mathrm{PF}$ in the weekly doses $(P<0.01)$. The increase in the DD had not reached statistical significance, however it remained to be significantly higher than the weekly groups (Table 3). The significant increase in the weekly groups was due to the efficient absorption of iron because of the right timing of the mucosal turn-over which occurs every 5 days. The 12 week duration of supplementation had allowed the building of iron reserves. The existing high levels of PF in the DD at 8 weeks might have resulted in decreased $F e$ absorption because absorption is dependent on the abundance of iron blockage caused by prolonged intake of high dose of iron was revealed by many scientist. ${ }^{12-14,63}$

The increase in PF without any further increase in $\mathrm{Hb}$ in the multi-nutrient supplemented groups reflects that the small amount of absorbed $\mathrm{Fe}$ may have entered the storage compartment because females were still $\mathrm{Hb}$ replete at 12 weeks (ranged from $130 \mathrm{~g} / \mathrm{L}$ to $131 \mathrm{~g} / \mathrm{L}$ ) suggeting that the existing $\mathrm{Hb}$ level was still adequate to maintain normal physiological functions.

The anemia rates in the multi-nutrient supplemented groups were: $\mathrm{DD}=7.8 \%$, WLD $=10.0 \%$; $\mathrm{WHD}=9.4 \%$ while PL had $24.0 \%$. The prevalence rates of LPF were: $\mathrm{DD}=4.7 \%$; $\mathrm{WLD}=15.7 \%$; $\mathrm{WHD}=18.8 \%$. The PL had increased in rate to $46.7 \%$. Prevalence rates in both anemia and LPF were similar between multi-nutrient supplemented groups $\left(X^{2}=P>0.05\right)$.

The DD resulted in a significant decrease in the prevalence of LPF levels at 8 weeks but slowed down to the level of the weekly groups at 12 weeks. This suggests that in situations where logistics and operational problems occur, the benefits of the WLD can be considered, it being economical, acceptable, and beneficial regimen in the prevention of ID and IDA. The persistent increase in the prevalence of LPF at 8 and 12 weeks in the PL group needs special concern.
When rapidity of recovery in PF is to be considered, then the DD is the dose of choice. This is congruent with the findings of Wright et al. ${ }^{64}$ However, daily dose of $\mathrm{Fe}$ could increase the incidence of unpleasant side-effects. The assessment of side-effects in this study might not be very reliable due to the occurrence of information bias, a rough conclusion may, however, be deduced on the available data. About $60 \%$ of females in the DD and WHD experienced discomforts while only $30 \%$ in the WLD. Nausea and vomiting were the common complaints. These abdominal discomforts might have been controlled when pills were taken after a meal. Most of the females in the study usually don't take breakfast at home which might have aggravated the occurrence of side-effects. Directions for use of iron pills needs an intensive nutrition education campaign. Other benefits on the administration of low dose need to be considered namely: prevention of the adverse interactive effects of high dose $F e$ on other essential minerals, like $Z n,{ }^{63,64 a}$ improved service delivery; increased coverage, and possible cost-cutting of $\mathrm{Fe}$ therapy programmes. In this study, the percentage of females taking the pills had decreased as the number of pills taken increased. This implies that they may be were simply bored of taking the pills. This boredness might have been counteracted if pills were only taken once weekly. The provision of WLD of multi-nutrient supplements in the schools provides an avenue for programmatic improvements of the present iron supplementation program.

The generally similar PR levels at 8 weeks reaching to a similar level at 12 weeks in the multi-nutrient supplemented groups (Table 3) implies that circulating PR in the body might had reached a plateau level. ${ }^{65}$

The level of PR in the blood in under homeostatic control over a broad range of body stores. ${ }^{66} \mathrm{PR}$ rises to a plateau that remains relatively constant until the liver becomes saturated at $300 \mu \mathrm{g} / \mathrm{g} .{ }^{65}$ Therefore, a reduced dose of 10 $000 \mathrm{IU}$ of vitamin A might be sufficient to maintain adequate plasma retinol levels. The prevalence of LPR was only found int the PL and it had increased from 7\% to $10.7 \%$ at the end of 12 weeks.

\section{Influencing Factors}

The different biochemical markers used to assess anemia in this study may be influenced by other factors like: other hemapoietic nutrients, parasitic infestation, and infections.

Since no female was found to have hypersegmented cells at baseline, 8 , and at 12 weeks (average lobe count in each group ranged from 2.9 to 3.2 ), it can be deduced 
Table 3. Hemoglobin, plasma ferritin and plasma retinol levels at baseline, 8 and 12 weeks ${ }^{1}$

\begin{tabular}{clll}
\hline Study groups (n) & Baseline & 8 weeks & 12 weeks \\
\hline Hemoglobin (g/L) & & & $130.9 \pm 7.8^{2,4}$ \\
Daily (64) & $127.6 \pm 11.0$ & $133.9 \pm 9.8^{2}$ & $130.5 \pm 7.8^{4}$ \\
Weekly,low (70) & $124,3 \pm 10,6$ & $131.0 \pm 8.9^{2}$ & $130.0 \pm 7.7^{2,4}$ \\
Weekly,high (64) & $126.2 \pm 10.6$ & $131.2 \pm 8.8^{2}$ & $124.6 \pm 8.8^{2,3,4}$ \\
Placebo (75) & $127.4 \pm 10.1$ & $126.0 \pm 8.6^{2,3}$ & $61.9 \pm 32.0^{3,4}$ \\
Plasma ferritin level ( $\mu$ g/L) & & & $42.3 \pm 21.9^{2,4}$ \\
Daily (64) & $34.7 \pm 22.0$ & $59.5 \pm 25.2^{2,3}$ & $44.8 \pm 27.2^{2,4}$ \\
Weekly,low (70) & $27,5 \pm 20,2$ & $37.3 \pm 24.7^{2}$ & $27.5 \pm 18.6^{2,4}$ \\
Weekly,high (64) & $30.6 \pm 25.6$ & $39.8 \pm 24.4^{2}$ & $1.17 \pm 0.18^{4}$ \\
Placebo (75) & $32.1 \pm 23.5$ & $29.0 \pm 22.3^{2}$ & $1.12 \pm 0.21^{4}$ \\
Daily (64) & & $1.12 \pm 0.21^{2}$ & $1.15 \pm 0.22^{2,4}$ \\
Weekly,low (70) & $0.87 \pm 0.22$ & $1.11 \pm 0.22^{2}$ & $0.86 \pm 0.16^{2,3,4}$ \\
Weekly,high (64) & $0.85 \pm 0.26$ & $1.07 \pm 0.21^{2}$ & $0.92 \pm 0.18^{2,3}$ \\
Placebo (75) & $0.81 \pm 0.25$ & & \\
\hline
\end{tabular}

${ }^{1} \overline{\mathrm{X}} \pm \mathrm{SD}$

ANOVA: basal $\mathrm{Hb} ; \mathrm{PF} ; \mathrm{PR}$ between groups, $\mathrm{P}=0.52 ; \mathrm{P}=0.32 ; \mathrm{P}=0.51$ respectively.

2 significantly different from previous measurements, $\mathrm{P}<0.005$

${ }^{3}$ significantly different from ${ }^{2}, \mathrm{P}<0.05$

${ }^{4}$ significantly different from baseline, $\mathrm{P}<0.005$

that the low $\mathrm{Hb}$ level in this study might be caused by poor iron and/or vitamin A status and not by folic acid.

One common practice in assessing whether anemia is due to IDA is the response in $\mathrm{Hb}$. An increase in $10 \mathrm{~g} / \mathrm{L}$ is indicative of ID. ${ }^{3}$ With this phenomenon, the still existing prevalence of anemia in the multi-nutrient supplemented groups which ranged from $7.8 \%$ to $10.0 \%$ might be caused by deficiency of other hemeforming nutrients like protein, pyridoxine, $\mathrm{Cu}, \mathrm{B}_{12}$, and $\mathrm{B}_{2}{ }^{24}$

The beneficial effect of deworming drugs on iron nutriture was not evident in this study. At baseline $34 \%$ of the female subsamples were infected with trichuris. Iron-folate supplements with deworming drugs had greater marked improvement in $\mathrm{Fe}$ status. ${ }^{67}$ In this present study, the effect was not evident because the placebo (PL) group, although given deworming drugs did not show an increase in iron status. It might be that trichuris infection did not cause enough blood loss to produce anemia, ${ }^{68}$ hence it is not the limiting factor of ID in this study.

The significant increase in PR in the PL group is unclear. Findings revealed that ascariasis lowers retinol concentrations, ${ }^{69,70}$ and fat absorption ${ }^{71}$ but the extent to which the control of trichuris had beneficial effects on plasma retinol remains unfounded.
The females did not have any infection as assessed clinically at 8 weeks and 12 weeks. This was confirmed by the results of the white blood cell count (WBC) which were within normal limits $\left(9 \pm 4.5 \times 10^{9} / \mathrm{L}\right)$. Only two females from the PL group had diarrhea for 1 day.

\section{Effects of multi-nutrient supplements on Physical Status, Frequency, and Duration of Supplementa- tion}

Many studies have revealed increased weight ${ }^{72-74}$ and linear growth. ${ }^{75}$ All of these studies however, had been observed in children where growth at this period is still rapid. Currently, there is no information on the effect of intervention in adolescents. ${ }^{50}$ This study is the first to reveal such information.

The increased weight in the DD and the WLD at 8 weeks (Table 4) may indicate increased dietary energy intake due to increased appetite attributed to the intake of multi-nutrient supplements. Basta et al ${ }^{76}$ revealed the same effect on iron supplemented latex tappers. At 12 weeks, weight in the WLD, WHD, and PL remained stable as the values at 8 weeks (Table 4) while there was a decreased weight in the DD group. The decrease might be partly due to decreased energy intake because of the fasting month. 
The significant increase in height between baseline through 12 weeks $(\mathrm{P}<0.005)$ which ranged from 0.4 $\mathrm{cm}$ to $0.5 \mathrm{~cm}$ in the multi-nutrient supplemented groups (Table 4) was higher than the expected normal increase in median height which is $0.1 \mathrm{~cm}$ per month using the height-for-age reference standards. ${ }^{45}$ This can be due to the improved iron status which enhanced oxidative processes resulting in more energy for cell proliferation. ${ }^{77}$ The PL had a cumulative increase of only $0.2 \mathrm{~cm}$. for 3 months. Since the increases in height, in the multi-supplemented groups were significantly higher than the PL group, it can be claimed that the increased height was the effect of the multinutrient supplements given.

This study suggests that although, linear growth decelerates during adolescents, an increase can be attained when the limiting factor of the nutritional insult is addressed but the increase fall short to compensate previous losses. Stunting is difficult to reverse when remedial actions are done later in life when growth spurt has already occured. ${ }^{50}$

BMI remained stable from baseline to 8 weeks, however, at 12 weeks the mean BMI in all groups had decreased (Table 4). Although dietary intake at 12 weeks was not collected, decreased BMI might be due to decreased energy intake in observance of the fasting month. This may be confounded by the tendency of adolescent females to often eat less than what is dictated by their appetite because of the fear of becoming fat. This was manifested in the high rate of low energy intake $(84.8 \%)$ at 8 weeks. Another factor to consider is, since weight gain lagged behind height gain, mean BMI had significantly declined at 12 weeks.

The persistently high prevalence of thinness should be given attention due to negative effects in future pregnancy and pregnancy outcome. Equally, the high rates of females at-risk of becoming overweight was very high (ranged from $30 \%$ to $40 \%$ ) in all group (Table 4). This may pose future health problems like hypertension, coronary heart disease, diabetes mellitus, and the presence of gallstones. ${ }^{44}$

Studies on the negative effects of iron deficiency on school performance in pre-school and school-aged children were revealed by many investigators. ${ }^{78-80}$ This may jeopardize education attainment due to poor mental and motor functioning later in increased mental and motor functioning. ${ }^{79}$ These studies, however, were carried-out among younger children.

\section{Effects of multi-nutrient supplements on School Performance Test Scores of female adolescents}

Biological development and organization of the brain in humans is very rapid in utero and starts to slow down in the second year of life. ${ }^{83}$ Although gross organization is nearly complete by 2 or 3 years, maturation may continue through adolescence and beyond. ${ }^{84}$ This is supported by the positive effect of multi-nutrient supplements in school performance in the present study. The significant increase in test scores in the PL may be attributed to the learning effect because the same set of questions were administered before and after the 8 weeks, and possible increased concentration and interest. These same factors may have also existed in the multi-nutrient supplemented groups. But since the increases were significantly higher in the multi-nutrient supplemented groups than the increase in the PL group, deduction may be made that the additional increase in mean test scores is contributed by the multi-nutrient pills (Table 5).

Although the mechanism has not been extensively studied, it can be reasoned out that the supplements given might have increased the supply of iron in the brain, and its distribution to the brain cells ${ }^{85}$ for the normal development and functioning of dopaminergic neurons. ${ }^{16}$

The mean IQ scores of the females which was assessed at the end of 8 weeks showed that there was a similar mean IQ test scores between groups, thereby, it did not show any confounding effect on the results of the school performance tests.

\section{Dietary intake}

Often, variance between individuals in dietary intake data is difficult to measure due to the flat slope syndrome incurred in $24-\mathrm{h}$ recall method. This may not serve as a valid marker to accurately quantitate energy and nutrient intake ${ }^{86}$ but results can still be used to give rough estimates. The present study, showed that energy, iron, vitamin $\mathrm{A}$ anda $\mathrm{C}$ intakes of females were similar between groups at 8 weeks. This indicates that increases in $\mathrm{Hb}, \mathrm{PF}, \mathrm{PR}$, and height, and school performance test scores can be attributed to the multi-nutrient supplements. 
Table 4. Antropometric indices at baseline, 8 , and 12 weeks

\begin{tabular}{|c|c|c|c|}
\hline Groups(n) & Baseline & 8 weeks & 12 weeks \\
\hline \multicolumn{4}{|l|}{ Weight } \\
\hline Daily (64) & $46.0 \pm 6.1^{3}$ & $46.2 \pm 6.2^{1}$ & $45.8 \pm 6.2^{1,3}$ \\
\hline Weekly,low (70) & $49.1 \pm 8.4^{3}$ & $49.3 \pm 8.7^{1}$ & $49.3 \pm 9.1^{3}$ \\
\hline Weekly,high (64) & $46.6 \pm 6.1$ & $46.7 \pm 6.1$ & $46.6 \pm 6.0$ \\
\hline Placebo (75) & $48.3 \pm 5.9$ & $48.3 \pm 5.9$ & $48.1 \pm 6.0$ \\
\hline \multicolumn{4}{|l|}{ Height } \\
\hline Daily (64) & $152.7 \pm 5.1$ & $153.0 \pm 5.1^{1}$ & $153.2 \pm 5.1^{1,2}$ \\
\hline Weekly,low (70) & $154.4 \pm 4.5$ & $154.6 \pm 4.5^{1}$ & $154.8 \pm 4.5^{1,2}$ \\
\hline Weekly,high (64) & $153.9 \pm 4.7$ & $154.1 \pm 4.8^{1}$ & $154.3 \pm 4.7^{1,2}$ \\
\hline Placebo (75) & $154.4 \pm 5.0$ & $154.5 \pm 5.1^{1}$ & $154.6 \pm 5.0^{1,2}$ \\
\hline \multicolumn{4}{|l|}{ BMI } \\
\hline Daily (64) & $19.7 \pm 2.4$ & $19.7 \pm 2.4$ & $19.5 \pm 2.4^{1,2}$ \\
\hline Weekly,low (70) & $20.6 \pm 3.1$ & $20.6 \pm 3.2$ & $20.5 \pm 3.3^{1}$ \\
\hline Weekly,high (64) & $19.7 \pm 2.6$ & $19.7 \pm 2.6$ & $19.6 \pm 2.6^{1,2}$ \\
\hline Placebo (75) & $20.3 \pm 2.4$ & $20.2 \pm 2.4$ & $20.1 \pm 2.4^{1,2}$ \\
\hline
\end{tabular}

values are expressed in means and SD

' significantly different from previous measurement; $\mathrm{P}<0.05$

2 significantly different from baseline, $\mathrm{P}<0.005$

${ }^{3}$ significantly different between group, $\mathrm{P}<0.05$

Table 5. School performance test scores of females at basline and 8 weeks

\begin{tabular}{llrr}
\hline Study groups (n) & Baseline & 8 weeks & Difference \\
\hline Daily (64) & $14.6 \pm 5.6$ & $23.8 \pm 7.5^{1}$ & $9.2 \pm 4.5^{3}$ \\
Weekly,low (70) & $13.3 \pm 4.9$ & $23.5 \pm 7.0^{1}$ & $10.2 \pm 4.6^{3}$ \\
Weekly,high (64) & $14.4 \pm 5.0$ & $23.3 \pm 6.6^{1}$ & $8.9^{3} \pm 4.2^{3}$ \\
Placebo (75) & $14.5 \pm 5.1$ & $19.5 \pm 5.2^{1}$ & $5.0 \pm 2.7^{2}$ \\
\hline
\end{tabular}

values are expressed in means and SD of raw tests scores

1 significantly different from previous measurement, $\mathrm{P}<0.002$

2 significantly different form ${ }^{3}, \mathrm{P}<0.05$

\section{FOLLOW-UP STUDY (36 WEEKS FROM BASELINE)}

\section{Retention of effects of multi-nutrient supplements on $\mathrm{Hb}, \mathrm{PF}, \mathrm{PR}$ levels}

The problem in a follow-up study is the loss of subjects as in the case of this study. Although $36.6 \%$ can no longer be located at the end of 36 weeks, analysis showed that mean $\mathrm{Hb}, \mathrm{PF}$, and PR levels of drop-outs were similar with the values of the remaining subjects. This suggests that should these females been located and reassessed, data obtained will be similar as the analyzed data.
The follow-up study revealed that the efficiency of the multi- nutrient supplements in restoring $\mathrm{Hb}$ at higher levels at 36 weeks observed in the WLD. The DD and WHD, although they had higher levels than baseline, values were not statistically different $(\mathrm{P}>0.05)$ (Table 6). The non-significant difference in $\mathrm{Hb}$ between baseline and 36 weeks, as well as between 12 weeks and 36 weeks in the DD and WHD might be due to the small remaining sample size and low calculated power index at 36 weeks. The reduced difference in $\mathrm{Hb}$ levels between baseline and 36 weeks signals the need for an intervention.

Retention of effects of the multi-nutrient supplements on iron stores as reflected by the significantly higher 
Table 6. Hemoglobin, plasma ferritin and plasma retinol levels of females at baseline, 12 and 36 weeks

\begin{tabular}{clll}
\hline Study group (n) & Baseline & 12 weeks & 36 weeks \\
\hline Hemoglobin (g/L) & & & \\
Daily (37) & $126.6 \pm 12.2$ & $130.7 \pm 7.8^{1}$ & $128.6 \pm 7.9^{4}$ \\
Weekly,low (45) & $123.6 \pm 9.7$ & $130.3 \pm 8.3^{1}$ & $126.9 \pm 9.5^{1,3}$ \\
Weekly,high (40) & $126.5 \pm 10.5$ & $130.3 \pm 8.0^{1}$ & $128.2 \pm 7.4^{4}$ \\
Placebo (50) & $126.0 \pm 9.1$ & $123.3 \pm 7.6^{1,2}$ & $120.5 \pm 7.9^{1,2,3}$ \\
Plasma ferritin ( $\mu$ g/L) & & & \\
Daily (37) & $34.7 \pm 20.7$ & $63.4 \pm 34.6^{1,2}$ & $40.6 \pm 23.9^{1}$ \\
Weekly,low (45) & $27.3 \pm 19.8$ & $41.8 \pm 20.4^{1}$ & $34.5 \pm 19.9^{1,3}$ \\
Weekly,high (40) & $29.2 \pm 22.2$ & $44.9 \pm 27.8^{1}$ & $35.5 \pm 23.9^{1,3}$ \\
Placebo (50) & $29.9 \pm 22.1$ & $27.4 \pm 18.7^{2}$ & $25.1 \pm 18.4^{1,2,3}$ \\
Plasma retinol ( $\mu$ mol/L) & & & \\
Daily (37) & $0.82 \pm 0.24$ & $1.18 \pm 0.19^{1}$ & $1.29 \pm 0.27^{1,3}$ \\
Weekly,low (45) & $0.79 \pm 0.24$ & $1.09 \pm 0.21^{1}$ & $1.29 \pm 0.24^{1,3}$ \\
Weekly,high (40) & $0.77 \pm 0.24$ & $1.16 \pm 0.22^{1}$ & $1.30 \pm 0.23^{4}$ \\
Placebo (50) & $0.76 \pm 0.23$ & $0.85 \pm 0.16^{1,2}$ & $0.93 \pm 0.18^{1,2,3}$ \\
\hline
\end{tabular}

values are in means and $\mathrm{SD}$, serum ferritin was log transformed for analysis

${ }^{1}$ significantly different from previous measurements, $\mathrm{P}<0.001$

2 significantly different from ${ }^{1,4}, \mathrm{P}<0.05$

3 significantly different from baseline, $\mathrm{P}<0.005$

PF levels at 36 weeks than at baseline was only observed in the weekly doses. The DD had a higher PF level at 36 weeks than at baseline but it did not reach statistical significance (Table 6). The decreased PF levels in the multi-supplemented groups from the intervention period (baseline) through 36 weeks reflects that iron stores were used for $\mathrm{Hb}$ synthesis. Further research with longer period is needed to determine the true stage of iron depletion. The PL had a continues decreasing values from baseline through 36 weeks (Table 6). Change in PF levels were similar in all multi-nutrient supplemented groups. Surprisingly, the PF levels in the DD had not increased significantly compared with baseline and that it had utilized its iron reserves very rapidly compared with the weekly doses. Further research is needed to confirm and seek biological significance on this finding.

The similar rates of anemia and LPF at 36 weeks indicates that there was no difference in dose-frequency-related effects that existed between the DD, WLD, and the WHD regimens of the multi- supplements.

Analysis (binomial proportions) showed that the probability of females to remain iron replete (PF $>20 \mu \mathrm{g} / \mathrm{L}$ ) after the multi- nutrient supplementation study was $55 \%$. This calculated value was higher than the expected value of $50 \%$ as stated in the hypothesis.
Results indicate that multi-nutrient supplements given once weekly with low dose retains greater benefits than the daily and weekly high dose in sustaining the iron needs of females for 6 months after 12 week supplementation. This has important implications in program planning. Longterm effects of iron supplements on Hb was also observed after 24 months in preschool children. ${ }^{87}$

\section{Retention of effects of multi-nutrient supplements on physical status}

At 36 weeks, mean weight, height, and BMI of dropouts were similar with the values of the remaining subjects. However, the drop-outs were older than the remaining subjects but it has not affected the analysis of the remaining data because anthropometric indices were calculated based on individual age of females.

The long-term effect of multi-nutrient supplements on physical growth was not evident on weight but maintained to be observed in linear growth (Table 7). The cumulative increase in height for 6 months from the termination of supplementation in the different groups were as follows: $D D=1.0 \mathrm{~cm}$, WLD $=0.7 \mathrm{~cm}$, $\mathrm{WHD}=0.7 \mathrm{~cm}, \mathrm{PL}=0.2 \mathrm{~cm}$. The increase was due to the cohort effect which implies the normal growth that they have to achieve over time, and to the effect of the 
multi-supplements given. The effect of the supplements was very evident because the increase in the PL was about 4-5 times lower than the multi-supplemented groups. The retention of effects of iron and vitamin $C$ supplements on physical growth was also revealed by Angeles et $\mathrm{al}^{88}$ in preschoolers. Further studies should be conducted to elucidate the increase in height due to supplementation during this period.

Effects of supplements on decreasing the prevalence of stunting did not show significant benefits. Marked degree of retardation incurred in early childhood generally remains into adulthood which implies that linear growth during adolescence seems to be minimal in populations which continue to reside in the same environment which gave rise to stunting in early childhood. ${ }^{50}$ Thinness and obesity were still high indicating urgent remedial measures (Table 7).

Table 7. Anthropometric indices at baseline, 12 and 36 weeks

\begin{tabular}{lccc}
\hline Groups(n) & Baseline & 12 weeks & 36 weeks \\
\hline Weight & & & \\
$\quad$ Daily (37) & $46.5 \pm 7.1$ & $46.6 \pm 7.2$ & $46.7 \pm 7.2$ \\
Weekly,low (45) & $48.5 \pm 7.9$ & $48.6 \pm 8.5$ & $49.1 \pm 8.4^{1,2}$ \\
Weekly,high (40) & $47.3 \pm 6.6$. & $47.2 \pm 6.6$ & $47.8 \pm 6.8$ \\
Placebo (50 & $49.0 \pm 5.9$ & $48.8 \pm 6.0$ & $49.0 \pm 6.1$ \\
Height & & & \\
Daily (37) & $152.1 \pm 5.3$ & $152.5 \pm 5.3^{1}$ & $153.5 \pm 5.5^{1,2}$ \\
Weekly,low (45) & $153.8 \pm 4.4$ & $154.2 \pm 4.4^{1}$ & $154.9 \pm 4.4^{1,2}$ \\
Weekly,high (40) & $153.3 \pm 4.4$ & $153.7 \pm 4.4^{1}$ & $154.4 \pm 4.5^{1,2}$ \\
Placebo (50) & $154.8 \pm 5.4$ & $155.1 \pm 5.4^{1}$ & $155.3 \pm 5.4^{1,2}$ \\
BMI & & & \\
Daily (37) & $20.1 \pm 2.6$ & $19.9 \pm 2.8$ & $19.8 \pm 2.7^{1,2}$ \\
Weekly,low (45) & $20.5 \pm 3.1$ & $20.4 \pm 3.4$ & $20.5 \pm 3.4$ \\
Weekly,high (40) & $20.1 \pm 2.9$ & $20.0 \pm 2.8$ & $20.0 \pm 2.7$ \\
Placebo (50) & $20.5 \pm 2.5$ & $20.3 \pm 2.5$ & $20.3 \pm 2.4$ \\
\hline
\end{tabular}

values are expressed in means and SD

I significantly different from previous measurement, $\mathrm{P}<0.05$

${ }^{2}$ significantly different from baseline, $P<0.05$

\section{Dietary intake}

Energy intake of females in all groups was less than the requirement for this age which is $2100 \mathrm{kcal} .{ }^{89}$ Improper eating habits may lead to undernutrition and aggravate the problem on anemia. The mean dietary and nutrient intakes of females remained similar between groups, thus, sustained high $\mathrm{Fe}$ status and increased height can be attributed to the long-term effects of supplementation.

\section{CONCLUSIONS AND RECOMMENDATIONS}

\section{Conclusions}

This study which started with a cross-sectional survey of 805 females and 118 males showed that there was a high prevalence of thinness in males $(43 \%)$ while high prevalence of overweight in females (33\%). A high prevalence of stunting (22\%) in both male and female school-going adolescents was also observed. Anemia was prevalent in females $(21 \%)$ but not in males $(2 \%)$.

Out from the 805 females, 272 had completed the intervention study for 12 weeks. At baseline, there was a high prevalence of anemia ( $21 \%$ ), low iron stores $(37 \%)$ as measured by plasma ferritin, and high prevalence of suboptimal level of plasma retinol (31\%). This condition justified the implementation of multi-nutrient supplements.

\section{Effects of multi-nutrient supplements}

Multi-nutrient supplements had improved the :

* hemoglobin and plasma ferritin levels

* vitamin A status as indicated by increased plasma retinol

* linear growth

* and school performance test scores of females

Females receiving placebo pills had poorer iron status.

\section{Frequency-dose effects of supplementation}

* The weekly doses either given in low $(60 \mathrm{mg}$ el iron) or high (120 mg el iron) had equally similar effects on all the biochemical indices, linear growth, and school performance test scores of the females.

* The daily supplements did not show any greater benefit in increasing the hemoglobin levels, school performance test scores, and physical growth over the weekly doses either given in high dose or in low dose. The beneficial effect of the DD over the weekly doses was the significant increase in plasma ferritin at 8 weeks.

* The DD and WHD showed higher incidence of side-effects. This might have been related to the timing of the consumption of multi-nutrient pills.

\section{Duration of supplementation}

Longer duration of multi-nutrient supplementation had not shown further increase in $\mathrm{Hb}$ and plasma retinol in 
all multi-nutrient supplemented groups but enabled the building of significantly higher iron stores only in the weekly doses. The existing prevalence of anemia even after 12 week supplementation may imply that this small portion of females in this study may be deficient in other hemeforming nutrients which were beyond the scope of this study like protein pyridoxine, $\mathrm{Cu}, \mathrm{B}_{12}$ and $\mathrm{B}_{2}$.

Multi-nutrient supplements had triggered and increase in linear growth as short as 8 weeks and continued to increase when supplementation was extended for 12 weeks. However, values fall short to compensate earlier losses during infancy and early childhood.

\section{Retention of effects}

All the multi-nutrient supplemented groups had retained significantly higher PR levels, and height. Significantly higher $\mathrm{Hb}$ level only in the WLD while higher PF levels in both the weekly doses were observed. The $\mathrm{Hb}$ and $\mathrm{PF}$ levels were on a declining level from the termination of the supplementation period to 36 weeks.

\section{Recommendations}

* It is highly recommended that combined multinutrient supplementation of iron, vitamin A, folic acid, and vitamin $\mathrm{C}$ be considered as a program to improve the health, nutritional status, and school performance test scores of female adolescents.

* It is recommended that weekly low dose (WLD) of $60 \mathrm{mg}$ el iron, $500 \mu \mathrm{g}$ folic acid, $20000 \mathrm{I} . \mathrm{U}$. of vitamin $\mathrm{A}$, and $60 \mathrm{mg}$ vitamin $\mathrm{C}$ is preferred because it is cheaper and feasible.

* The duration of 12 weeks is adequate to build iron reserves.

* Periodic supplementation is every 6 months is advisable to maintain adequate iron stores.

* Further research is recommended to: confirm the findings of this study in a larger population; assess the role of other hemopoietic nutrients protein $\mathrm{Cu}$, $B_{2}$, pyridoxine $\left(B_{6}\right)$, and $B_{12}$; the effect of a reduced dose of $10000 \mathrm{IU}$ vitamin $\mathrm{A}$; assess the actual period of iron depletion; and operational research on service delivery system.

* A well-balanced mix ranging from short, medium, and long-term strategies to prevent ID and IDA should be implemented.

- Remedial measures (like supplementation) to decrease the prevalence of stunting should be done in early childhood during the growth periods to attain better impact.
- Nutrition education on proper food intake and food habits should be an indispensable component of the program. Clear directions on pill intake should also be an integral part of the program to avoid the occurence of side-effects.

* Establish linkage between government and nongovernment organizations to effectively and efficiently carry-out the program.

\section{REFERENCES}

1. Kodyat B, Djokomoelyanto, Karyadi D, Tarwotjo, Muhilal, Husaini, Sukaton A. Micro-Nutrient Malnutrition. Ministry of Health, Directorate General of Community Health, Directorate of Community Nutrition, Jakarta, Indonesia, 1991.

2. Gross R, Angeles-Agdeppa IT, Schultink WJ, Soemilah S, Drupadi. Daily versus weekly iron supplementation: Programmatical and economic implication for Indonesia. Food and Nutrition Bulletin (accepted for publication), 1996.

3. WHO/UNICEF/UNU. Indicators and strategies for iron deficiency and anemia programmes. WHO, Geneva, 1994.

4. Indonesia Demographic and Health Survey (IDHS). Central Bureau of Statistics, State Ministry of Population/National Planning Coordinating Board, Ministry of Health. IDHS, Macro International Inc., Maryland, 1994.

5. Schultink W, Van der Ree M, Matulessi P, Gross R. Low compliance with an iron supplementation program: a study among pregnant women in Jakarta, Indonesia. Am J Clin Nutr 1993; 57:135-9.

6. Thorand B, Schultink WJ, Gross R, Soemilah S, Wentzel S. Efficiency of iron supplementation programme for pregnant women in Jeneponto, Sulawesi, Indonesia. Asia Pacific J Clin Nutr 1994; 3:211-5.

7. Herbert V. Hematology and the anemias. In: Nutritional Support of Medical Practice (Schneider A, Anderson C, Coursin D., eds), $2^{\text {nd }}$ ed, Philadelphia: Harper and Row 1983; 386-92.

8. Schultink W, Gliwitzki M, Gross R, Matulessi P. Daily versus intermittent doses of iron supplements among preschool children. Am J Clin Nutr 1995; 61:111-5.

9. Gross R, Schultink W, Juliawati. Treatment of anemia with weekly iron supplementation: Lancet 1994; 334:821.

10. Martin A, Tolomei $\mathrm{K}$, Viteri FE. Iron metabolism in iron supplemented rats. FASEB J 1994; 4: A1076.

11. Liu X-N, Zhang J, Yen H, Viteri F. Hemoglobin and serum ferritin levels in pregnant Chinese women in response to weekly iron supplements. Paper presented at the Symposium on selected strategies for the control of nutritional anemia. 7th Asian congress of Nutrition. Beijing (abstract), 1995.

12. Fairweather-Tait SJ, Minski MJ. Studies on iron availability in man, using stable isotope techniques. Br J Nutr 1986;55:279-85

13. O'Neill-Cutting MA, Crosby WH. Blocking of iron absorption by a preliminary oral dose of iron. Arch Int Med 1987; 147: 489-91. 
14. Viteri FE. Iron deficiency in children: New possibilities for tits control. International Child Health 1995; 6:49-61.

15. ACC/SCN. Combating iron deficiency: can weekly supplementation be effective? No.13, 23, 1996.

16. Scrimshaw N. National Strategies for Overcoming Micronutrient Malnutrition Nutrition Paper of the Month of September. World Health Organization Assembly. 1992; 1-19.

17. FAO/WHO. International Conference on Nutrition: Major Issues for Nutrition Strategies. Geneva 1992.

18. Hunt JR, Gallagher SK, Johnson L. Effect of ascorbic acid on apparent absorption by women with low iron stores. Am J Clin Nutr 1994; 59: 1381-5.

19. Combs, Gerald F. Vitamin C. In: The Vitamins: Fundamental Aspects in Nutrition and Health. Califomia: Academic Press Inc, 1992; 225-49.

20. Hodges RE, Sauberlich HE, Canham JE, Wallace DL, Rucker RB, Mejia LA, Mohanram M. Hematopoietic studies in vitamin A deficiency. Am J Clin Nutr 1978; 31: 876-85.

21. Thurnham D. Vitamin A, iron and hemopoiesis. Lancet 1993;342:1312-3 (editorial).

22. Suharno D, West C, Muhilal, Karyadi D, Hautvast J. Supplementation with Vit $\mathrm{A}$ and iron for nutritional anemia in pregnant women in West Java, Indonesia. Lancet, 1993: 342:1325-7.

23. Tanumihardjo S, Suhamo D, Permaesih D, Muherdiyantiningsih, Dahro A, Muhilal, Karyadi D, Olson J. Application of the modified relative dose response test to pregnant Indonesian women for assessing vitamin A status. Eur J Clin Nutr 1995;49:897-903.

24. Guthrie HA. Nutrition from Childhood through Adulthood. In: Introductory Nutrition. Missouri: Times Mirror/Mosby College Publishing Co, 1986; 568-70.

25. Senderowitz J. Adolescent Health: Reassessing the Passage to Adulthood. World Bank Discussion Paper\#272. Washington DC: The World Bank, 1995.

26. REPELITA V. Indonesian Long Term Development Plan. Republic of Indonesia.

27. Dallman P. Changing iron needs from birth through adolescence. In: Nutritional Anemias (Fomon SJ, Zlotkin S., eds). Nestle Nutrition Services New York: Raven Press vol 30, $1992 ; 29-35$.

28. National Research Council. Recommended Dietary Allowances Subcommittee on the Tenth Edition of RDA's. Food and Nutrition Board, Commission on Life Sciences, Washington, DC: National Academy Press, 1989; 195-203.

29. WHO. Basic Laboratory Methods in Medical Parasitology. WHO, Geneva, 1991; 25-7.

30. International Nutritional Anemia Consultative Group (INACG). Interpretation of Iron Status. In: Measurement of iron status (Cook J, Dallman PR, Boothwell T, Lynch SR, Covell AM, Worwood MA, Reusser ME., contributors) Washington DC, 1985; 72-6.

31. Hallberg L, Bengtsson C, Lapidus L, Lundberg PA, Hulten L. Screening for iron deficiency: an analysis based on bonemarrow examinations in population sample of women. $\mathrm{Br} \mathbf{J}$ Hematol 1993; 85: 787-8.
32. Wintrobe MM, Lee RG, Boggs DR, Bithell TC, Athens JW, Foerster J. Clinical Hematology. 7th ed. Philadelphia, 1974;5466-579.

33. Dacie SJ, Lewis SM. Practical Hematology. New York: Churchill Livingstone 1991; 37-123.

34. International Vitamin A Consultative Group (IVACG). Biochemical Methodology for the Assessment of Vitamin A Status. Washington DC: The Nutritional Foundation 1982.

35. Must A, Dallal GE, Dietz WH. Reference data for obesity: 85th and 95th percentiles of body mass index $\left(w t / \mathrm{ht}^{2}\right)$ and triceps skinfold thickness. Am J Clin Nutr 1991; 53:839-46.

36. WHO Expert Committe. Adolescents. In: Physical Status: The Use and interpretation of Anthropometry. WHO technical Report series \#854. WHO, Geneva, 1995; 263-306.

37. Nelson M. Indonesian nutrient analysis program. University of Indonesia, Jakarta, 1996.

38. FAO/WHO. Requirements of vitamin A, iron, folate, and vitamin $B_{12}$. Report of a joint FAO/WHO Expert Consultation. Food and Nutrition Series No.23. Rome: FAO, 1988.

38a. Hassard TH. Understanding Biostatistics. Missouri: MosbyYear Book, Inc., 1991.

39. Cattell R. Culture Fair Intelligence Test. Institute for Personality and Ability Training, Illinoid, 1974.

39a. Norman GR, Streiner DL. Biostatistics: The Bare Essentials. St. Louis Missouri, Mosby 1994.

40. Council for International Organizations of Medical Sciences. International Guidelines for Ethical Review of Epidemiological Studies. Geneva, 1991.

41. Durnin JVGA. Low body mass index, physical work capacity and physical activity levels. Eur J Clin Nutr 1994; 48: suppl 3;s39- 444 .

42. Kusin J, Karjati S, Renvist U. Maternal body mass index: the functional significance during reproduction. Eur J Clin Nutr 1994; 48:suppl.3;s56-s67.

43. Strickland $S$, Ulijaszek S. Body mass index and illness in Sarawak. Eur J Clin Nutr 1994; 48:suppl.98-109.

44. Garrow J. Obesity and related diseases. Edinburgh: Churchill Livingstone, 1988.

45. WHO. Measuring Change in Nutritional Status. WHO. Geneva, 1993.

46. Baumgartner $R$, Roche A, Himes J. Incremental growth tables: supplementary to previously published charts. Am J Clin Nutr 1986; 711-22.

47. Micozzi M, Albanes D, Stevens R. Relation of body composition to clinical biochemical and hematologic indices in US men and women. Am J Clin Nutr 1989; 50: 1276-81.

48. Karlberg J, Jalil F, Lam B, Low L, Yeung C. Linear growth retardation to three phases of growth. Eur J Clin Nutr 1994; 48: suppl.1; s25-s44.

49. Waterlow JC. Causes and mechanisms of linear growth retardation (stunting). Eur J Clin Nutr 1994;48:suppl 1, s1-s4.

50. Martorell R, Khan K, Schroeder D. Reversibility of stunting: epidemiological findings in children from developing countries. Eur Clin Nutr 1994; 48:supll 1, s45-s57.

51. Maclure M, Yravis L, Willett W, MacMahon B. A prospective cohort study of nutrient intake and age at menarche. Am J Clin Nutr 1991; 54: 649-56. 
52. Rees M. Menarche when and why? Lancet 1993;342:137576.

53. Hallberg L, Hulten L, Bengtsson C, Lapidus L, Lindstedt G. Iron balance in menstruating women. Eur J Clin Nutr 1995; 49: 200-7.

54. Mejia LA, Chew F. Hematological effect of supplementing anemic children with $V$ it $A$ alone and in combination with iron. Am J Clin Nutr 1988;48:595-600.

55. Ridwan E, Schultink W, Drupadi D, Gross R. Effects of weekly iron supplementation of pregnant Indonesian women are similar to those of daily supplementation. Am J Clin Nutr 1996; 63:884-90.

56. Dodd N, Sheela T, Sharma U. Effect of different levels of iron supplementation on the iron status and physical work capacity of anemic Indian women. Indian J Med Sci. $1992 ; 46: 2 ; 33-42$.

57. Tanumihardjo S, Muherdiyantiningsih, Permaesih D, Komala, Muhilal, Karyadi D, Olson J. Daily supplements of vitamin A ( $8.4 \mathrm{mmol}, 800 \mathrm{IU})$ improve the vitamin A status of lactating Indonesia women. Am J Clin Nutr 1996;63:3235.

58. Stoltzfus R, Hakimi M, Miller K, Rasmussen K, Dawiesah $S$, Habitch JP, Dibley M. High dose vitamin A supplementation of breast- feeding Indonesian mothers: effects on vitamin A status of mother and infant. J Nutr 1993; 123:66675.

59. Bloem M, van Agtmaal E, Speek A, Schreus W. Vitamin A intervention: Short-term effects of a single oral, massive dose on iron metabolism. Am J Clin Nutr 1990;51:76-9.

60. Wolde-Gebriel Z, West C, Haile Gebru, Tadesse A, Fisshes T, Gare P, Ayana G, Hautvast JGAJ. Interrelationship between vitamin $A$, iodine and iron status in school children. Int J Vit Nutr Res 1993;47:389-93.

61. Muhilal, Permaesih D, Idjradinata Y, Muherdiyantiningsih, Karyadi D. Vitamin A-fortified monosodium glutamate and health, growth and survival of children: a controlled field trial. Am J Clin Nutr 1988:48:suppl.595; 1271-6.

62. Mejia LA, Arroyave G. The effect of vitamin A fortification of sugar on iron metabolism in preschool children in Guatemala. Am J Clin Nutr 1982; 36: 87-93.

63. Solomons NW, Pineda O, Viteri F, Sandstead H. Studies on bioavailability of zinc in humans: mechanism of the intestinal interaction of nonheme iron and zinc. J Nutr 1985; 113:337-49.

64. Wright JA, Southon S. The effectiveness of various ironsupplementation regimens in improving the Fe status of anemic rats. Br J Clin Nutr 1990;63:579-85.

64a. Simmer K, James C, Thompson RPH. Are iron and folate supplements harmful. Am J Clin Nutr 1987;45:122-5.

65. Bates C, Thurnham D, Bingham S, Margetts B, Nelson M. Biochemical Markers of Nutrient Intake. In: Design Concepts in Nutrition Epidemiology (Margetts B, Nelson M.eds), New York: Oxford University Press 1991; 192-254.

66. WHO/UNICESS. Indicators for assessing vitamin A deficiency and their application in monitoring and evaluating intervention programmes. Geneva, Switzerland, 1992.

67. Atukorala S, de Silva D, Dechering W, Dassenaeike T, Perera R. Evaluation of effectiveness of iron-folate sup- plementation and anthelminthic therapy against anemia in pregnancy-a study in the plantation sector of Sri Lanka. Am J Clin Nutr 1994; 60:286-92.

68. Stephenson LS. Impact of Helminth Infections on Human Nutrition. London: Taylor \& Francis Ltd, 1987.

69. Jalal F, Nesheim M, Sanjur D, Habitch J. Effects of deworming, dietary fat intake and carotenoid rich diets on vitamin $A$ status of ascaris lumbricoidess infected preschool children in West Sumatra, Indonesia. FASEB J 4: A503 (abstract), 1990.

70. Marinho H, Shrimpton R, Guigliano R, Burini R. Influence of internal parasites on the blood vitamin A levels in preschool children orally supplemented with retinol and/or zinc. Eur J Clin Nutr 1991; 45: 539-44.

71. Mahalanabis D, Halan K, Maitra T, Agarawal S. Vitamin A absorption in ascaris. Am J Clin Nutr 1976; 29: 1372-75.

72. Lawless JW, Latham MC, Stephenson LS, Kinot SN, Pertet AM. Iron supplementation improves appetite and growth in anemic Kenyan school children. J Nutr 124: 1994; 645-54.

73. Chwang L, Soemantri A, Pollitt E. Iron supplementation and physical growth of rural Indonesian children. Am J Clin Nutr 1988; 47: 496-501.

74. Aukett M, Parks Y, Scotts P, Wharton B. Treatment with iron increases weight gain and psychomotor development. Arch. Dis Child 1988; 61: 849-57.

75. Angeles IT, Schultink W, Matullessy F, Gross R, Soemilah $S$. Decreased rate of stunting through iron supplementation. Am J Clin Nutr 1993; 58: 339-42.

76. Basta S, Soekirman D, Karyadi D, Schrimshaw N. Iron deficiency anemia and worker productivity of adult males in Indonesia. Am J Clin Nutr 1979; 32: 916-25.

77. Passmore R, Eastwood M. The anemias. In: Human Nutrition and Dietetics. ELBS, 8th ed. 1986; 459-64.

78. Pollitt E, Hathirat P, Kotchabhakdi N, Missell L, Valyasevi A. Iron deficiency and educational achievement in Thailand. Am J Clin Nutr 1989; 50:687-97.

79. Soewondo M. Hussaini M, Pollitt E. Effects of iron deficiency on attention and learning processes in preschool children: Bandung, Indonesia. Am J Clin Nutr 1989; supl.50:666-74.

80. Soemantri AG, Pollitt E, Kim I. Iron deficiency anemia and educational achievement. Am J Clin Nutr 1989; 42: 1221-28.

81. Levin H, Pollitt E, Galloway R, McGuire. Micronutrient Deficiency Disorders: Health Sector Priority Review, vol 1, The World Bank, 1991; 1-5.

82. Lozoff B, Jimenez E, Abraham W. Long term developmental outcome of infants with iron deficiency. New Eng J Med 1991; 325: 687-94.

83. Dobbing $\mathrm{J}$. Vulnerable periods in developing brain. Brain, Behavior, and Iron in the Infant Diet. London: Springer-Verlag 1990; 1-25.

84. Jernigan TL, Trauner DA, Hesselink JR, Tallal PA. Maturation of the human cerebellum observed in vivo during adolescence. Brain 1991; 114: 2037-49.

85. Beard J. One person's view of iron deficiency, development, and cognitive function. Am J Clin Nutr 1995; 62: 709-10. 
86. VanStaveren W. Validation of food intake measurements. In: Proceedings of the XIII International Congress of nutrition. London: John Libbey and Co Ltd. 1985;697-9.

87. Angeles IT, Gross R, Schultink W, Soemilah S. Dillon D. Is there a long-term effect of iron supplementation on anemia alleviation? Am J Clin Nutr 1995; 62:440-1 (letter).
88. Kusin J, Karjati S, Renvist U. Matemal body mass index: the functional significance during reproduction. Eur J Clin Nutr 1994;48:suppl 3;s56-67.

89. Garrow J. Obesity and related diseases. Edinburg: Churchill Livingstone, 1988. 